\title{
Pengaruh Media Tumbuh yang Berbeda terhadap Kandungan Air, Protein dan Lemak Maggot Black Soldier Fly (Hermetia illucens)
}

\section{(Effects of different culture media on nutritive value of Maggot Black Soldier Fly)}

\author{
Maulana ${ }^{1}$, Nurmeiliasari ${ }^{2 *}$, Yosi Fenita ${ }^{2}$ \\ ${ }^{1}$ Alumni Program Studi Peternakan Fakultas Pertanian Universitas Bengkulu \\ 2 Jurusan Peternakan, Fakultas Pertanian, Universitas Bengkulu. \\ JI. WR Supratman Kandang Limun Bengkulu, Indonesia.
}

*Penulis Korespondensi: sari_nurmeiliasari@unib.ac.id

Dikirim (received): 01 September 2021; dinyatakan diterima (accepted): 24 Oktober 2021; terbit (published): 15 November 2021. Artikel ini dipublikasi secara daring pada https://ejournal.unib.ac.id/index.php/buletin_pt/index

\begin{abstract}
This study aimed to evaluate nutritional content of maggot Black Soldier Fly grown in diverse culture media. This research was conducted from August to October 2020 in Mukomuko Regency, Bengkulu Province and in the laboratory of the Department of Animal Husbandry, Bengkulu University. The design of this study was a completely randomized design (CRD) consisting of 4 treatments and 3 replications. In this study, various growth media were used, namely decanter solid (M1), Tofu dregs (M2), Coconut dregs (M3) and Oil palm fronds (M4). The variables observed in this study were water content (KA\%), crude protein (PK\%) and crude fat (LK\%). Data analysis was carried out by analysis of variance, if the analysis had a significant effect $(P<0.05)$, then Duncan Multiple Range Test (DMRT) was performed. The results showed that different culture media affected the air content $(P<0.05)$, crude protein content $(P<0.01)$ and the weight of fresh maggots $(P<0.0 \%)$. However, they had no significant effect $(P>0.05)$ on the crude fat content. The media that produced the lowest water content of Maggot BSF were tofu dregs $(77.14 \pm 0.53 \%)$; The best growing media producing the highest maggot protein content was coconut pulp growing medium $(37.71 \pm 0.54 \%)$ and the best growing medium producing the highest fresh maggot weight was tofu pulp growing medium $(380.67 \pm 43.11 \mathrm{~g})$. To sum up, various culture media are attributable to changes in nutritional contents of maggot.
\end{abstract}

Key words: maggot, culture media, nutritional content

\section{ABSTRAK}

Penelitian ini bertujuan mengevaluasi pengaruh media tumbuh yang berbeda terhadap kandungan air, protein dan lemak maggot BSF. Penelitian ini dilaksanakan bulan Agustus - Oktober 2020 di Kabupaten Mukomuko Provinsi Bengkulu dan Laboratorium Jurusan Peternakan Universitas Bengkulu. Desain penelitian ini adalah Rancangan Acak Lengkap (RAL) yang terdiri dari 4 perlakuan dan ulangan sebanyak 3 ulangan. Pada penelitian ini menggunakan berbagai media tumbuh yaitu Lumpur Sawit (M1), Ampas Tahu (M2), Ampas Kelapa (M3) dan Pelepah Sawit (M4). Analisis data dilakukan dengan analisis ragam, apabila analisis berpengaruh nyata $(P<0,05)$ maka dilakukan Duncan Multiple Range Test (DMRT). Hasil penelitian yang diperoleh menunjukkan bahwa media tumbuh berbeda mempengaruhi kandungan air $(P<0,05)$, tidak berpengaruh nyata $(P>0,05)$ pada parameter kandungan lemak kasar dan signifikan mempengaruhi kandungan protein kasar $(P<0,01)$ dan berat segar maggot BSF yang dihasilkan. Media yang menghasilkan kadar air Maggot BSF yang terendah yaitu ampas tahu $(77,14 \pm 0,53 \%)$; media tumbuh yang terbaik menghasilkan kadar protein maggot tertinggi adalah media tumbuh ampas kelapa $(37,71 \pm 0,54 \%)$ dan media tumbuh yang terbaik menghasilkan berat segar maggot tertinggi adalah media tumbuh ampas tahu $(380.67 \pm 43,11 \mathrm{~g})$. Berbagai media tumbuh maggot menyebabkan perubahan pada komposisi gizi maggot.

Kata kunci: Maggot, media tumbuh, kandungan nutrisi maggot 


\section{PENDAHULUAN}

Industri pengolahan hasil pertanian adalah bidang usaha yang memproduksi limbah. Produksi limbah yang terus menerus mencemari lingkungan dan merusak ekosistem. Kondisi ini berdampak buruk bagi kesehatan. Menurut badan pusat statistik Indonesia BPS (2013), dalam kurun waktu 2004-2012 jumlah industri pengolahan pertanian meningkat dari 896.267 unit menjadi 1.036 .531 unit atau peningkatannya sebesar $1,96 \%$ per tahun.

Peningkatan jumlah industri pengolahan pertanian menyebabkan produksi limbah akan bertambah. Maggot BSF dapat dijadikan sebagai salah satu bahan baku alternatif dalam pakan buatan karena dapat diproduksi secara budidaya dengan memanfaatkan limbah produk pertanian seperti ampas tahu, bungkil sawit, lumpur sawit, ampas kelapa dan pelepah sawit (Fasakin et al., 2003).

BSF adalah spesies lalat tropis yang mempunyai kemampuan mengurai materi

Limbah dari industri pengolahan hasil pertanian yang sering dijumpai dan jarang dimanfaatkan adalah solid, ampas tahu, ampas kelapa dan pelepah sawit. Limbah tersebut memiliki kandungan nutrisi yang cukup tinggi sehingga jika dimanfaatkan dapat berguna dan akan mengurangi pencemaran lingkungan. Lekito (2002) dan Mathius et al. (2004) melaporkan kandungan zat-zat nutrisi lumpur kelepa sawit yaitu protein kasar $11,94 \%$ - 12,17\%, serat kasar 21,15\% - 29,76\%, lemak 10,40\% - 19,69\%, selulosa $11,42 \%$, hemiselulosa $18,77 \%$ dan lignin $36,40 \%$. Ampas tahu mempunyai protein sebesar 26,82\% dan lemak kasar13,72\% (Aldi et al., 2018). Ampas kelapa merupakan limbah dengan kadar potein $11,35 \%$ serta serat kasar 14,97\% (Miskiyah et al., 2006). Pelepah sawit mengandung zat-zat nutrisi bahan kering $48,78 \%$, protein kasar 5,3\%, hemiselulosa $21,1 \%$, selulosa $27,9 \%$, serat kasar $31,09 \%$, abu $4,48 \%$, BETN 51,87\%, lignin 16,9\% dan silika 0,6\% (Imsya, 2007). organik dengan sangat baik (Holmes et al., 2012) dan sudah digunakan sebagai agen pengurai limbah organik (Rachmawati et al., 2010). Limbah dari industri pengolahan hasil pertanian dapat di manfaatkan salah satunya adalah untuk media pembiakan maggot BSF untuk bahan pakan sumber protein. Bosch et al. (2014) menyatakan kandungan protein maggot BSF yaitu 40-50\% dengan kandungan lemak berkisar 29-32\%.

BSF atau lalat tentara hitam adalah salah satu insekta yang mulai banyak dipelajari karakteristiknya dan kandungan nutriennya. Selain itu Bullock et al. (2013) menyatakan BSF bukan lalat hama dan merupakan jenis lalat yang memiliki risiko penyebaran penyakit yang lebih rendah dibanding jenis lalat lainnya. $\mathrm{Li}$ et al. (2011) memperkuat pernyataan tersebut dengan menjelaskan lalat ini bukan merupakan lalat hama dan tidak dijumpai pada pemukiman dengan penduduk yang banyak sehingga bukan merupakan ancaman bagi kesehatan.

Media tumbuh maggot sangat penting untuk kualitas maggot yang dihasilkan. Media tumbuh yang berbeda akan menghasilkan maggot dengan kandungan nutrisi yang berbeda (Oliver, 2004). Kandungan protein yang tinggi pada media akan berpengaruh baik terhadap protein maggot. Merunut dari uraian diatas maka studi terhadap media tumbuh yang tepat untuk kehidupan maggot perlu dilakukan. Tujuan dari penelitian ini adalah untuk mengetahui pengaruh media tumbuh yang berbeda terhadap kandungan KA, PK dan LK maggot BSF.

\section{METODE PENELITIAN}

Tempat dan Waktu Penelitian

Penelitian ini dilaksanakan pada bulan Agustus - Oktober 2020 di Desa Teruntung Kecamatan Teras Terunjam Kabupaten Mukomuko Provinsi Bengkulu dan Laboratorium Jurusan Peternakan Fakultas Pertanian Universitas Bengkulu. 


\section{Alat dan Bahan}

Alat yang digunakan dalam penelitian ini adalah ember, toples plastik, serokan, waring, parang, blender, cangkul, karung, palu, paku, kantong plastik, timbangan digital, timbangan manual, gunting, nampan, saringan, terpal, dan alat tulis. Bahan-bahan yang digunakan dalam penelitian ini adalah lumpur sawit, ampas tahu, ampas kelapa, pelepah sawit, garam, air dan telur Black Soldier Fly (BSF).

Persiapan Tempat Pemeliharaan Maggot Black Soldier Fly (Hermetia illucens)

Telur BSF ditetaskan di dalam toples. Saat telah menetas, pemeliharaan dilakukan di dalam ember-ember tempat pemeliharaan maggot diletakkan pada tempat yang aman dari hujan dan panas matahari langsung.

Persiapan Media Tumbuh Maggot Black Soldier Fly (Hermetia illucens)

Media tumbuh maggot yaitu solid atau media lumpur sawit didapatkan dari salah satu pabrik kelapa sawit yang ada di telur diletakkan. Pada saat umur maggot BSF berusia 3 hari, dipindahkan ke dalam ember yang berisi media tumbuh maggot BSF masingmasing ulangan sebanyak $1,5 \mathrm{~kg}$. Pada saat umur maggot BSF berusia 6 hari media tumbuh ditambah sebanyak $2 \mathrm{~kg}$. Saat umur maggot BSF berusia 9 hari media tumbuh ditambahkan lagi sebanyak $2 \mathrm{~kg}$. Setiap hari dilakukan pengadukan media tumbuh maggot BSF yang sudah menetas supaya media tumbuh yang digunakan dapat dimakan oleh maggot BSF secara merata.

Pemanenan Maggot Black Soldier Fly (Hermetia illucens)

Maggot BSF dipanen pada fase larva umur dua minggu dengan menggunakan larutan garam yang dibuat dari 500 gram dilarutkan
Kabupaten Mukomuko. Ampas tahu sebagai media lainnya di dapatkan dari pembuat tahu dengan skala industri rumah tangga. Ampas kelapa didapatkan dari penjual santan kelapa di pasar dan pelepah sawit dikumpulkan dari sekitar perkebunan kelapa sawit. Pelepah sawit dicacah sebelum dijadikan media tumbuh maggot. Uji proksimat kandungan nutrisi media berupa KA, PK dan LK dilakukan di laboratorium.

Penetasan Maggot dan Pemeliharaan Maggot Black Soldier Fly (Hermetia illucens)

Penelitian ini menggunakan telur BSF sebanyak 12 gram yang didapat melalui pemesanan telur BSF di aplikasi jual beli online. Telur BSF yang dibeli dari aplikasi jual beli online ditetaskan pada toples plastik yang berisi media tumbuh. Telur BSF seberat 1 gram diletakkan pada tisu. Selanjutnya telur pada kertas tisu diletakkan di atas media.

Media yang digunakan untuk penetasan telur BSF adalah lumpur sawit, ampas tahu, ampas kelapa dan pelepah sawit. Media ditimbang masing-masing ulangan sebanyak $0,5 \mathrm{~kg}$.

pada air sebanyak 5 liter. Selanjutnya dilakukan penimbangan untuk mendapatkan berat segar maggot seperti yang dijelaskan Aldi et al. (2018).

Penjemuran Maggot Black Soldier Fly (Hermetia illucens)

Setelah pemanenan maggot dijemur tiga hingga empat hari sampai kering. Setelah kering kemudian ditimbang dan dicatat berat kering udara (BKU).

Penggilingan Maggot Black Soldier Fly (Hermetia illucens) Menjadi Tepung

Penggilingan maggot BSF menjadi tepung dilakukan setelah maggot dijemur sampai kering. Maggot BSF yang sudah kering digiling 
menggunakan blender sampai halus menjadi tepung dan disaring. Tepung BSF yang halus ditempatkan pada kantung plastik dan diberi label.

\section{Metode Perlakuan}

Penelitian ini menggunakan 4 perlakuan pada pertumbuhan maggot di media yang berbeda dan setiap perlakuan menggunakan 3 ulangan. Perlakuannya sebagai berikut, Lumpur Kelapa Sawit (M1), Ampas Tahu (M2), Ampas Kelapa M3) dan Pelepah Sawit (M4).

\section{Parameter yang Diamati}

Beberapa parameter yang diamati dalam penelitian ini adalah kadar air (KA\%), protein kasar (PK\%) dan kadar lemak kasar (LK\%).

\section{Rancangan Percobaan}

Rancangan penelitian yang digunakan adalah Rancangan Acak Lengkap (RAL), terdiri atas 4 perlakuan dan 3 ulangan.

\section{Analisis Data}

Data proksimat pada media tumbuh dijelaskan secara deskriptif. Data kandungan nutrisi maggot meliputi kandungan air, protein dan lemak yang dihasilkan dari berbagai media tumbuh dianalisis dengan metode analisis ragam. Uji Duncan's Multiple Range Test akan dilakukan jika hassil analisis ragam nenunjukkan pengaruh nyata (Steel dan Torrie,1995).

\section{HASIL DAN PEMBAHASAN}

Nutrisi pada Media Tumbuh Maggot Black Soldier Fly (Hermetia illucens)

Data komposisi kimia media tumbuh yang didapatkan dari analisis proksimat yang dilakukan terhadap media tumbuh maggot BSF disajikan pada Tabel 1.

Tabel 1. Kandungan nutrisi pada media tumbuh maggot black soldier fly

\begin{tabular}{lccc}
\hline Media & Kadar Air & $\begin{array}{c}\text { Protein Kasar } \\
\text { Lumpur Sawit }\end{array}$ & \multicolumn{4}{c}{ Lemak Kasar } \\
Ampas Tahu & 82,03 & 15,60 & 16,74 \\
Ampas Kelapa & 78,33 & 24,11 & 29,75 \\
Pelepah Sawit & 80,01 & 5,71 & 36,6 \\
\hline
\end{tabular}

Kandungan nutrisi media tumbuh maggot BSF dengan uji proksimat diperoleh (Tabel 1). Pada media lumpur sawit mengandung kadar air sebesar $82,03 \%$; protein kasar sebanyak $15,60 \%$ dan lemak kasar sebesar $16,74 \%$. Ampas tahu mempunyai kadar air sebanyak 78,33\%; protein kasar sebesar $24,11 \%$ dan lemak kasar sebesar 29,75\%. Ampas kelapa memiliki kadar air sebesar 80,01\%; protein kasar sebanyak 5,71\% dan lemak kasar sebesar $36,6 \%$. Media tumbuh terakhir yaitu pelepah sawit mengandung kadar air sebesar
79,45\%; protein sebanyak 2,49\% dan lemak kasar sebanyak $1,09 \%$.

Kandungan Air Maggot Black Soldier Fly (Hermetia illucens)

Media tumbuh mempengaruhi kandungan air maggot BSF yang dihasilkan $(P<0,05)$. Kandungan air maggot BSF yang ditampilkan pada Tabel 2.

Media kelapa sawit menghasilkan maggot BSF dengan kadar air tertinggi dibandingkan media lainnya yaitu $80,26 \pm 0,63 \%$. Sebaliknya, maggot yang tumbuh pada media 
ampas kelapa memiliki kadar air terendah yaitu $77,14 \pm 0,53 \%$.

Berdasarkan hal tersebut kandungan air yang terdapat pada maggot BSF diperoleh dari kandungan air yang terdapat pada media tumbuh maggot BSF yang digunakan. Menurut Tomberlin, (2009) yang menyatakan bahwa maggot BSF yang sudah dewasa tidak membutuhkan asupan nutrisi atau tidak makan lagi kecuali air. Karena maggot membutuhkan air pada fase larva untuk

Tabel 2. Kandungan air maggot black soldier fly pada media tumbuh yang berbeda

\begin{tabular}{|c|c|c|c|c|}
\hline \multirow{2}{*}{ Media } & \multicolumn{3}{|c|}{ Ulangan (\%) } & \multirow{2}{*}{ Rataan-SD } \\
\hline & 1 & 2 & 3 & \\
\hline Lumpur Sawit & 80,60 & 78,49 & 77,94 & $79,01 \pm 1,40 \mathrm{ab}$ \\
\hline Ampas Tahu & 77,66 & 76,61 & 77,26 & $77,14 \pm 0,53^{a}$ \\
\hline Ampas Kelapa & 78,01 & 79.71 & 77,17 & $78,30 \pm 1,29 a b$ \\
\hline Pelepah Sawit & 80,04 & 79,77 & 80,97 & $80,26 \pm 0,63^{b}$ \\
\hline
\end{tabular}

Keterangan: Angka yang diikuti superskrip yang berbeda pada kolom yang sama menunjukkan perbedaan yang sangat nyata $(P<0,01)$

Hasil uji lanjut dengan Duncan's Multiple Range Test menunjukkan bahwa kadar air maggot BSF yang dihasilkan dengan menggunakan media tumbuh yang berbeda berpengaruh nyata $(P<0,05)$. Hal ini dapat disimpulkan bahwa penggunaan media tumbuh maggot BSF yang berbeda berpengaruh terhadap kandungan air maggot BSF yang dihasilkan. reproduksi, sehingga media tumbuh maggot BSF yang mengandung kadar air yang tinggi akan mempengaruhi pertumbuhan maggot yang dihasilkan. Pernyataan tersebut sama dengan pernyataan Fahmi, (2015) bahwa maggot BSF bersifat menyerap air yang terdapat pada media tumbuhnya sehingga dapat mempengaruhi kadar air yang terdapat pada maggot BSF yang dihasilkan.
Kandungan Protein Maggot Black Soldier Fly (Hermetia illucens)

Media tumbuh mempengaruhi kandungan kadar protein kasar maggot BSF yang dihasilkan $(P<0,01)$. Kandungan protein kasar pada media tumbuh bervariasi seperti yang diperlihatkan pada Tabel 1. Kadar protein kasar pada maggot yang tumbuh pada media yang berbeda tertera pada Tabel 3 .

Tabel 3. Kandungan protein kasar maggot black soldier fly pada media tumbuh yang berbeda

\begin{tabular}{lcccc}
\hline \multirow{2}{*}{ Perlakuan } & \multicolumn{3}{c}{ Ulangan (\%) } & \multirow{2}{*}{ Rataan-SD } \\
\cline { 2 - 4 } & 1 & 2 & 3 & \\
\hline Lumpur Sawit & 32,49 & 31,07 & 27,53 & $30,36 \pm 2,55^{\mathrm{b}}$ \\
Ampas Tahu & 31,19 & 32,93 & 39,27 & $34,46 \pm 4,25^{\mathrm{ab}}$ \\
Ampas Kelapa & 37,99 & 38,05 & 37,09 & $37,71 \pm 0,54^{\mathrm{a}}$ \\
Pelepah Sawit & 1,25 & 3,31 & 2,68 & $2,41 \pm 1,06^{\mathrm{c}}$ \\
\hline
\end{tabular}

Keterangan: Angka yang diikuti superskrip yang berbeda pada kolom yang sama menunjukkan perbedaan yang sangat nyata $(P<0,01)$

Rata-rata kandungan kadar protein kasar maggot BSF dari yang tertinggi sampai ke yang terendah yaitu $37,71 \pm 0,54 \%$ diperoleh dari media tumbuh ampas kelapa, 34,46 $\pm 4,25 \%$ diperoleh dari media tumbuh ampas tahu, $30,36 \pm 2,55 \%$ diperoleh dari media tumbuh lumpur sawit dan $2,41 \pm 1,06 \%$ diperoleh dari media tumbuh pelepah sawit. 
Berdasarkan penjelasan tersebut, kadar protein maggot BSF yang yang diperoleh sangat dipengaruhi oleh kandungan nutrien yang ada pada media tumbuh. Hasil uji proksimat, media yang paling tinggi kandungan protein kasarnya yaitu ampas tahu, sedangkan maggot BSF yang menghasilkan protein yang lebih tinggi terdapat pada media tumbuh ampas kelapa. Silmina et al. (2010) menyatakan nilai protein yang tinggi tidak menjamin kebutuhan nutrisi untuk pertumbuhan maggot BSF yang terdapat di media cocok bagi pertumbuhan maggot. Duponte dan Larish, (2003) menegaskan media yang banyak mengandung bahan organik sangat mempengaruhi pertumbuhan dan kandungan nutrisi maggot yang akan dihasilkan. Secara metabolisme maggot dapat mengkonversi protein dan berbagai nutrient menjadi biomassa maggot (Suciati dan Faruq, 2017).

Kandungan nutrisi media tumbuh maggot sangat menentukan nutrisi maggot yang akan dihasilkan nantinya semakin bagus kualitas nutrien yang terdapat pada media tumbuh maka maggot yang dihasilkan juga mengandung nutrien yang bagus. Aldi et al. (2018) menyatakan bahwa media yang memiliki kuantitas serta kualitas tinggi akan berdampak positif terhadap kuantitas serta kualitas protein maggot yang dihasilkan.

Keseimbangan antara kandungan air, kadar lemak, kadar protein dan nutrisi lainnya penting untuk tumbuh kembang maggot. Jika di dalam media tumbuh maggot mengandung protein yang tinggi sedangkan kandungan lemaknya rendah maka maggot BSF yang dihasilkan tidak maksimal begitupun sebaliknya jika di dalam media tumbuh maggot mempunyai kandungan lemak yang tinggi sedangkan kandungan proteinnya rendah maka maggot BSF yang dihasilkan juga tidak maksimal. Dari hasil uji proksimat media dan maggot BSF yang dihasilkan dapat disimpulkan bahwa kandungan protein yang tinggi tidak menjamin kandungan protein maggot yang dihasilkan tinggi jika kandungan lemak medianya rendah.

Pengaruh Media Tumbuh yang Berbeda Terhadap Kandungan Lemak Maggot Black Soldier Fly (Hermetia illucens)

Rata-rata kandungan kadar lemak kasar dengan uji proksimat yang terdapat pada maggot BSF yang dihasilkan (Tabel 4). Kandungan lemak kasar maggot BSF dari yang tertinggi sampai ke yang terendah $40,95 \pm 1,93 \%$ diperoleh dari media tumbuh ampas tahu, 38,10 $\pm 2,54 \%$ diperoleh dari media tumbuh ampas kelapa, 37,04 $\pm 24,94 \%$ diperoleh dari media tumbuh pelepah sawit dan $32,16 \pm 4,81 \%$ diperoleh dari media tumbuh lumpur sawit.

Hasil analisis ragam (Anova) menunjukkan bahwa media tumbuh yang berbeda tidak berpengaruh nyata $(P>0,05)$ terhadap kandungan lemak kasar maggot BSF yang dihasilkan. Hal ini, berarti media tumbuh maggot BSF yang berbeda pada penelitian ini tidak dapat mempengaruhi kandungan lemak kasar maggot yang dihasilkan.

Berdasarkan uji proksimat media tumbuh maggot BSF yang digunakan pada penelitian ini kandungan lemak kasar pada media tumbuh maggot lumpur sawit 16,74\%; pada media tumbuh maggot ampas tahu $29,75 \%$; pada media tumbuh maggot ampas kelapa $36,6 \%$ dan pada media tumbuh maggot pelepah sawit $1,09 \%$. (Tabel 1 ).

Hasil analisis ragam yang dilakukan menunjukkan bahwa media tumbuh maggot BSF yang berbeda tidak berpengaruh terhadap kandungan lemak kasar maggot BSF yang dihasilkan. Biasanya kandungan nutrisi yang terdapat pada media tumbuh maggot mempengaruhi kandungan nutrisi yang terdapat pada maggot yang dihasilkan karena maggot mengambil nutrisi yang ada pada media tumbuh untuk pertumbuhannya diantaranya zat nutrisi yang digunakan adalah kandungan lemak dan protein (Arief, et al 2012). 
Tabel 4. Kandungan lemak kasar maggot black soldier fly pada media tumbuh yang berbeda

\begin{tabular}{lcccccc}
\hline \multirow{2}{*}{ Perlakuan } & \multicolumn{3}{c}{ Ulangan (\%) } & \multirow{2}{*}{ Rataan-SD } & Keterangan \\
\cline { 2 - 4 } & 1 & 2 & 3 & & \\
\hline Lumpur Sawit & 28,10 & 37,47 & 30,92 & & $32,16 \pm 4,81$ & Non-significant \\
Ampas Tahu & 43,13 & 39,47 & 40,24 & & $40,95 \pm 1,93$ & Non-significant \\
Ampas Kelapa & 36,99 & 36,31 & 41,01 & & $38,10 \pm 2,54$ & Non-significant \\
Pelepah Sawit & 62,46 & 12,61 & 36,04 & $37,04 \pm 24,94$ & Non-significant \\
\hline
\end{tabular}

Saat maggot BSF mengurai media tumbuhnya terjadi peningkatan dan penurunan kandungan kadar protein dan kadar lemak ( Putra dan Ariesmayana, 2020).

Pengaruh Media Tumbuh yang Berbeda Terhadap Berat Segar Maggot Black Soldier Fly (Hermetia illucens)

Berat segar maggot dipengaruhi oleh media tumbuh $(P<0.05)$. Berdasarkan hasil penelitian yang dilakukan rataan berat maggot BSF dari yang tertinggi sampai ke yang terendah adalah sebagai berikut: $380.67 \pm$ 43,11gram dihasilkan oleh media tumbuh ampas tahu, 259,00 $\pm 38,59$ gram dihasilkan oleh media tumbuh ampas kelapa, $188.67 \pm$ 36,30 gram didapatkan dari media tumbuh lumpur sawit dan $138.33 \pm 16,80$ gram diperoleh dari media tumbuh pelepah sawit (Tabel 5).

Tabel 5. Berat segar maggot black soldier fly pada media tumbuh yang berbeda

\begin{tabular}{|c|c|c|c|c|c|}
\hline \multirow{3}{*}{ Media } & \multicolumn{3}{|c|}{ Berat Segar Maggot (g) } & \multirow{3}{*}{ Jumlah } & \multirow{3}{*}{ Rataan \pm SD } \\
\hline & \multicolumn{3}{|c|}{ Ulangan } & & \\
\hline & 1 & 2 & 3 & & \\
\hline Lumpur Sawit & 150 & 222 & 194 & 566 & $188.67 \pm 36,30^{c}$ \\
\hline Ampas Tahu & 389 & 419 & 334 & 1142 & $380.67 \pm 43,11^{a}$ \\
\hline Ampas Kelapa & 219 & 296 & 262 & 777 & $259.00 \pm 38,59 b$ \\
\hline Pelepah Sawit & 142 & 120 & 153 & 415 & $138.33 \pm 16,80^{c}$ \\
\hline
\end{tabular}

Keterangan: Angka yang diikuti superskrip yang berbeda pada kolom yang sama menunjukkan perbedaan yang sangat nyata $(P<0,01)$.

Satu gram telur maggot BSF yang tumbuh pada media yang berbeda menghasilkan berat segar yang bervariasi. Media tumbuh merupakan faktor yang menentukan berat maggot yang dihasilkan sesuai pernyataan Salman et al. (2020).

\section{KESIMPULAN}

Berdasarkan hasil penelitian yang dilakukan disimpulkan bahwa, media tumbuh maggot BSF yang berbeda pada penelitian ini berpengaruh terhadap kadar air, kadar protein kasar dan berat segar maggot, tetapi tidak berpengaruh terhadap kadar lemak maggot BSF yang dihasilkan. Maggot yang tumbuh pada media tumbuh ampas tahu memiliki kadar air terendah. Kadar protein maggot tertinggi adalah pada media tumbuh ampas kelapa $(37,71 \pm 0,54 \%)$ dan media tumbuh yang menghasilkan berat segar maggot tertinggi adalah media tumbuh ampas tahu $(380.67 \pm 43,11 \mathrm{~g})$. 


\section{DAFTAR PUSTAKA}

Aldi, M., F. Fatul., S. Tantalo dan Erwanto. 2018. Berbagai media tumbuh terhadap kandungan air, protein dan lemak Maggot yang dihasilkan sebagai pakan. Bandar Lampung. Jurnal riset dan inovasi peternakan. Vol 2 (2):14-20.

Arief, M., N. A. Ratika dan M. Lamid. 2012. Pengaruh kombinasi media bungkil kelapa sawit dan dedak padi yang difermentasi terhadap produksi maggot black soldier fly (Hermetia illucens) sebagai sumber protein pakan ikan. Jurnal Ilmiah Perikanan dan Kelautan. 3: 17-20

Bosch, G., S. Zhang., G. A. B. O. Dennis and H. H. Wouter. 2014. Protein quality of insects as potential ingredients for dog and cat foods. J Nutr Sci. 3:1-4.

BPS. 2013. Statistik Indonesia, Jakarta.

Bullock, N., E. Chapin., A. Evans., B. Elder., M. Givens., N. Jeffay., B. Pierce and W. Robinson. 2013. The Black Soldier Fly - How to Guide. Ontario: University of Windsor.

Duponte, M. W and L. B. Larish. 2003. Tropical Agriculture and Human Resource. Hawaii

Fahmi, M. R. 2015. Optimalisasi proses biokonversi dengan menggunakan mini larva hermetia illucens untuk memenuhi kebutuhan pakan ikan. Jurnal Ilmiah Perikanan dan Kelautan. 1: 139-144

Fasakin, E. A., A. M. Balogun and O. O. Ajayi. 2003. Evaluation of full-fat and defatted maggot meals in the feeding of clariid catfish Clarias gariepinus fingerlings. Aquacult. Res. Vol. 34 (9): 733-738.

Holmes, L. A., S. L. Vanlaerhoven and J. K. Tomberlin. 2012. Relative humidity effects on the life history of Hermetia illucens. (Diptera: Stratiomyidae). Environmental Entomology. Vol 41(4): 971-978.

Imsya, A. 2007. Konsentrasi N-amonia, kecernaan bahan kering dan kecernaan bahan organik pelepah sawit hasil amoniasi secara in vitro. Prosiding Seminar Teknologi Peternakan dan Veteriner, 21 - 22 Agustus 2007.
Puslitbang Peternakan Badan Litbang Pertanian, Deptermen Pertanian Bogor. p. 111 $-115$.

Lekito, M. N. 2002. Analisis kandungan nutrisi lumpur minyak sawit (Palm Oil Sludge) asal pabrik pengolahan di Kecamatan Prafi Kabupaten Manokwari Propinsi Papua. Jurnal Peternakan dan Lingkungan. Vol 8 (1): 59 -62.

Li, Q., L. Zheng., N. Qiu., H. Cai., J. K. Tomberlin and Z. Yu. 2011. Bioconversion of dairy manure by Black Soldier Fly (Diptera: Stratiomyidae) for biodiesel and sugar production. Waste Manag. 31:1316-1320.

Mathius, I.W., B. P. Azmi., D. M. Manurung., Sitompul dan E. Pryatomo. 2004. Integrasi Sawit-Sapi: Imbangan pemanfaatan produk samping sebagai bahan dasar pakan. Prosiding Sistem Integrasi Tanaman-Ternak. Denpasar. Juli 2004: 439-446 Rev. 34 367-369.

Miskiyah, I. M dan W. Haliza, 2006. Pemanfaatan ampas kelapa limbah pengolahan minyak kelapa murni menjadi pakan, in Presiding Seminar Nasional Tekhnologi Peternakan dan Verteriner.

Oliver, P. A. 2004. The bio-conversion of putrescent wasted. ESR LLC. Washington. P. 190

Putra, Y. dan A. Ariesmayana. 2020. Efektifitas penguraian sampah organik menggunakan maggot (bsf) di pasar rau trade center. Jurnalis: Jurnal Lingkungan dan Sipil. 3, 1 (Jul. 2020), 11-24.

Rachmawati., D. Buchori., P. Hidayat., S. Hem., M.R. Fahmi. 2010. Perkembangan dan Kandungan Nutrisi Larva Hermetia illucens (Linnaeus) (Diptera: Stratiomyidae) pada Bungkil Kelapa Sawit. Jurnal Entomologi Indonesia, Vol 7 (1): 28-41

Salman, N., E. Nofiyanti dan T. Nurfadhilah. 2020. Pengaruh dan efektivitas maggot sebagai proses alternatif penguraian sampah organik kota di Indonesia. Jurnal Serambi Engineering. ;5(1).

Silmina, D., E. Gabbie dan P. Mardian. 2010. Efektifitas berbagai media budidaya terhadap pertumbuhan maggot Hermetia illucens. 
Jurnal ilmiah Balai Penelitian Ternak Bogor Vol 11(3): 1-9

Steel, R. G. D and J.H. Torrie. 1990. Prinsip dan Prosedur Statistik. Suatu Pendekatan Biometrik. Alih Bahasa Ir.B.Soemantri. Ed II. Gramedia Jakarta.

Suciati, R. 2017. Efektifitas media pertumbuhan maggots Hermetia illucens (lalat tentara hitam) sebagai solusi pemanfaatan sampah organik. Biosfer: Jurnal Biologi Dan Pendidikan Biologi, Vol. 2(1), pp.8-13.

Tomberlin, J. K and D. C. Sheppard. 2002. Factors influencing mating and oviposition of Black Soldier Flies (Diptera: Stratiomyidae) in a colony. J Entolomogy Sci. 37:345-352. 